\title{
Performance Management Practices: A Case Study of Bank Al-Habib Pakistan
}

\author{
Ayesha Yaseen (Corresponding author) \\ Department of Management Sciences, The Islamia University of Bahawalpur \\ Email: Ayesha_ayesha12@hotmail.com
}

Sehrish Afghan

Department of Management Sciences, The Islamia University of Bahawalpur

\begin{abstract}
Received: March 05, 2016 Accepted: April 27, 2016 Published: May 22, 2016
doi:10.5296/ijhrs.v6i2.9430 URL: http://dx.doi.org/10.5296/ijhrs.v6i2.9430
\end{abstract}

\begin{abstract}
Purpose: This paper explores the relation between exercising different aspect of performance measures, connection to reward, and with the performance management systems (PMSs) effectiveness. It investigates the problems faced by the employees and appraiser in this system thus recommending the steps taken by the appraiser for the improvement of the employee's performances in financial institutions.
\end{abstract}

Methodology: primary and secondary data was collected. Qualitative and quantitative methodology is used by survey questionnaire and interviewing random sample of 30 respondents from bank Al-Habib. Furthermore it's an exploratory study as it explores problems in performance management system of Bank Al-Habib.

Findings: The performance management system of financial institution of Pakistan especially bank Al-Habib are fairly focused towards performance related outcomes, and less concerned about the realization of end product like training and development of employees. The results showed the strong relation between exercising different aspect of performance measures, connection to reward, and with the performance management systems (PMSs) effectiveness. Various variables were identified in influencing the effectiveness of PMS.

Practical implications: Findings showed that the financial institutions of Pakistan need to improve the efficiency of their PMS. It's far advance and better now but still there's a room for improvement.

Originality/value: This study may assist bank managers in identifying flaws and overcoming them regarding their PMS. It also provide the clear idea about the factors influencing the 
effectiveness of PMSs in the Banking context

Keywords: Performance management, Financial institutions, Banking sector

\section{Introduction}

Performance Management System is a process of setting objectives aligned to organizational goals, making plans to achieve those objectives and achieving those already set desired results. It has two components appraising performance and its development. More studies are realizing the significance of performance management pre-requisites, planning and its successful execution by generating formal documented framework and strategies. It is thought-out to be a central ingredient to ensure organizational success. This paper describes about the Performance Management System which is followed in bank Al-Habib. It also describes the problems faced by the employees and management in this system and elaborates the steps taken by the appraisers to improve the performances of the employees so that their efficiency can be amplified and later the rewards and recognitions are given in the form of promotions, enticements and incentives.

\section{Literature Review}

This research project is a review based on theory as well as the industrial outlook of PMS of Bank Al-Habib. This paper starts with the Introduction of performance management system that outlines its history, definitions, objective, types, process, strategies, appraiser, and considerations for evaluation and essentials that makes it more effective.

\subsection{History}

Performance management continues to be one of the most significant and criticized course of action. It has become progressively essential as a result of a multiple economic demands. Globalization increases struggle and now the focus is more towards individualistic employee relationship as compared to group employee relationship as some of the major factors that improved visibility and need of PMS (Williams, 2002).

\subsection{Definitions of Performance Management System}

PMS is a functional structure of communicating important information top to bottom to employees in an organization. It can be used as a mean to perform number of diverse function; as it tells convey organizational goals to all employees and help them with their training and development necessities, developing individual and team performance, future planning, measurement and evaluation of output (Armstrong and Baron, 1998a).

Performance management system is not a particular thing it's a multi-dimensional thing (Williams, 2002).

Main purpose of performance appraisal is to reach at desired workforce decisions by the accountability of employee's performance. It is also the process of taking, examining and documenting information about the comparative value of an employee (Dowling, Welch and 
Schuler, 1999; Moorhead and Griffin, 1992).Hartog (2004) further explains that: "Performance management encompasses the challenges or ambiguities organizations come across while identifying, evaluating, and motivating employee performance and aligning it with the effective organizational output. It is process for developing mutual agreement about what and how to be attained, furthermore it deals with and develop people in order to implify the prospect that desired goals will be obtained in the short and longer time frame" Armstrong and Baron (1998a).if individuals are well aware and confident about the participative nature of this process and have a clear idea about what is being expected from them will perform better than those who are unaware about the expected performance. The flow and approving of goals should be by mutual consent. Armstrong and Baron (1998a).The role of performance management systems is noteworthy because it enables organizations to identify areas of deprived performance and establish corrective measures (Theron, 2000). It ensures that human resources recognize the expectations of their immediate boss and appraiser should know whether the performance of an employee is according to the mandatory organizational objective (RSA, 1997; Thorpe and Beasley, 2004).De Waal and Counet (2009) specify the need for research on troubles related with the implementation and use of a performance management system. De Waal and Counet (2009: 368) through light on the continuous research and development in performance management system in an institute, the organization had to deal with the number of identical problems repeatedly and deteriorate results "inadequacy, time-consuming assignments and tasks, lead time, delays finally termination of PMS"

\subsection{Components of Performance Management}

PMS includes a wider range of actions, along with persistent comments (Roberts, 1998). Appraiser and employees sit together to discuss and review performance in a shared way to identify new objectives, development and training targets (DenHartog et al., 2004), guiding employees like a coach (Latham et al., 2005), motivating employees and societal aspect(Fletcher, 2001).

Performance management system has two components performance appraisal and performance development.

- Performance management:

$>$ Dynamic, nonstop process.

$>$ Develop organizational effectiveness.

$>$ Strategic aims.

- Performance appraisal:

$>$ Periodic event after a specific time period.

$>$ Formal appraise and review.

$>$ Last phase in performance management process. 
Mondy, R. (2008)

Performance Appraisal - "is a discreet process which most organizations perform once a year or semi-annually at divisional level to evaluate employees' performance." (Schultz, H.2003:74).

\subsection{Importance of Performance Management System}

Managing performances of all employees in an organization is a critical thing since long. Now it is considered very significant by the virtue of globalization. Balance scorecard system is introduced to quantify human resource elements, to maintain a flow of system top to bottom, employees are introduced with corporate strategy and to ensure that strategic plan are executed in real, performance management is the important supportive process that aid an institution in aligning organizational goals with individual goals. PMS further facilitates in explaining how the overall operational objectives are translated into organizational strategies and ultimately translated into goals. PMS involves all levels of management in operational planning process so that employees can be given chances to shape plans mutual coalition can help them to buy-in the process (Aguilar, 2003). Performance management is a process by which performance is developed and improved and it provides different ways to motivate employees that make them effective (DeNisi and Pritchard, 2006). Better performance management can directly improve financial performance. A study carried out by McDonald and Shield of Hewitt Associates showed that organizations that worked hard in managing performance prudently had better cash flows, high rate of return, high stock value and better stock market performance than organizations not working much on it. Performance management can improve following things:

- Financial performance

- $\quad$ Productivity

- Sales per employees (Rheem, 1995).

\subsection{Performance Management System in Financial Institutions (Banks)}

Currently financial institutions are trying harder to compete well by availing better opportunities through investment and expanding its branches in different countries. In addition to expansion banks are exploring certain ways to increase their efficiency and gaining competitive advantage by managing employee performance and finding. It seems to be that cost leadership can help banks in gaining competitive advantage. In order to gain cost leadership financial institutions need to cut down or reduce its operating expense that includes half of the total revenue that is salaries (Payant, 2006). These operating costs and its interlinked costs should be managed rationally that will perk up profitability and will help banks to gain competitive advantage through human resources.

\subsection{Performance Management Process}

Performance management process starts with planning behaviors and results. 


\subsubsection{Prerequisites and performance planning}

First step of performance management process is to examine prerequisites and performance planning. Prerequisites include knowledge of the vision and mission statement of an organization and knowledge of the job followed by job analysis and job description. Next step is performance planning that include setting performance standard and accepted behaviors. London et al (2004) argue that pre-requisites and pre-planning is very important in terms of mutually agreed participative goal setting. If this process is participative or two way then the performance is always improved rather than assigning goals to subordinates without any participation. Even though the aim is to improve performance that can only be achieve by setting goals. Besides improving performance an organization can communicate expectation, through attainment of goals and improved quality an organization can boost confidence of their personnel and job satisfaction (Locke and Latham 1984).

\subsubsection{Behaviors}

It's very crucial for an organization to recognize and proactively plan the most appropriate behavior that is in accordance with job requirements and aligned with organizational objectives. Performance is measured on the basis of two things results output oriented measurement and behavior based measurement. Performance management system helps organization in developing such processes that build up desired behaviors in human resource thus growing the preferred culture within an organization. This will ultimately assist an organization in achieving human capital advantage (Armstrong and Baron 2005).

\subsection{Performance Execution}

Next step of performance management process is to execute and implementation of performance planning and to monitor continuously where employees fails to meet the already set standards and giving feedback to them to get them back on track. London et al (2004) evaluate that the most important and main part of this process is setting goals and for that three things should be considered first that managers should be trained on how to identify and set goals. Secondly ensuring that whether those goals are aligned with overall organizational objectives or not. Third thing to be considered is the evaluation and appraisal of actual performance. Continuous monitoring according to the already set objectives plays a vital role after setting mutually agreed (Armstrong and Baron 2005). This is a major responsibility of the line manager to review their employee performance. "Performance appraisal is basically a chain of actions all the way through which the evaluation of employees performance and development of their proficiency, enhance performance and distributing rewards" (Fletcher 2001). Appraisal helps employees to improve their performance by providing the system to give effective feedback according to the goals (Williams 2002). Feedback is considered to be "One of the simplest ways of improving performance, motivation and relationships" in spite of this; appraisal controls actions of employees at work (Newton and Findlay 1996) and is discussed critically in literature. Hendry et al (2000) suggest that appraisal organize employees' activities by planning thus can be misused. Coates (1994, cited in Torrington et al (2005) suggests that the appraisal is a tool that matches individuals according to the organization. 


\subsection{Performance Assessment and Performance Review}

Fletcher (2004) explained that so many drawbacks are associated with performance appraisal making this process highly risky for administration. Newton and Findlay (1996) highlights the performance appraisal being the effective and extensive part of performance management and it's vulnerable to biasness and manipulation by supervisor. Appraisal is a continuous process of reviewing performance and formal written exercise to be held once or twice a year. It has changed now from merely paper-based activity to an ongoing process (Armstrong and Baron 2005).

"Associating rewards tactics to business objectives" (Gratton 1996) total rewards extrinsic and intrinsic rewards can motivate employees to perform well according to the overall organizational goals.

\subsection{Performance Management Skills}

- Communication skills.

- Coaching and mentoring.

- Giving constructive feedback.

- Compassion and empathy.

- Joint effort or team work.

\subsection{Reinforcement by Monetary and Non-Monetary Rewards}

High performance is reinforced by monetary rewards but now organizations are giving more importance towards non-monetary rewards to motivate their employees. Reward includes monetary benefits, like pay and non-monetary benefits like recognition. Organizations are recognizing the significance of non-financial rewards is as influential as financial incentives (Armstrong 2002). Non-monetary benefits are termed as recognition, employee of the week, accelerated career paths, freedom to make decisions, dual career paths, flexible working hours and for shaping enhancing abilities training and development opportunities (Williams 2002). Job satisfaction and organizational commitment is highly influenced by total reward system that includes extrinsic and intrinsic rewards (Armstrong and Baron 2005). Implementation of system should be discouraged that is merely based on the experience of appraisers of what they value themselves instead importance should be given towards knowing whether which type of rewards are appreciated by employees only those rewards should be promoted and encouraged (Hendry et al 2000), explained that: there should be number of different ways adopted by the organization to deal with different employees in order to motivate them(Torrington et al (2005). Brown (2001) argued that now we are in the world talent war and it's essential to execute the best suitable yet flexible reward strategies, which will encourage the retention of the competent employees within the organization. According to Helm et al. (2007), a performance management system which associates performance and reward or salary can have the most wanted effect on the outcome of PMS and in improving the insight of employees and this argument is also supported by Ohemeng 
(2009).

\subsection{Employee and Performance Development}

Performance managements system includes employee and performance development. Recently an increased stress on employee development has been taken and to a great extend on how targets are achieved you can say means rather than end result (Gratton 1996). It's an amalgam of output and input output in terms of objectives and input in terms of competencies (Taylor, 2005)Personal development planning (PDPs) provide employees the chances of maximum training sessions enhancing their skills and abilities moreover it boost self-confidence and performance thus acknowledgment as an elementary part of a PMS (White 1999). Beard well et al (2004) suggested that organizational success is purely dependent on Staff management and development.

\subsection{Poor implementation of Performance Management System}

It's in the hands of line manager whether PMS will be successful or not and how they interpret or implement the processes. Supervisors are consequently crucial in recent PMS and decisive in motivating employees and their "flexible behavior". Consistently cascading to the line manager within an organization the execution implementation of a performance management system is directed (Currie and Procter 2001, Whittaker and Marchington, 2003, Harrison, 2005).

Poorly implemented PMS can result in following:

- Fake and misleading information.

- Increased lay off.

- Wastage of time and money.

- Broken relationships.

- Diminishing motivation.

- Job frustration.

- Risk of lawsuit.

- Unfair values and standards.

Armstrong and Baron (2002) defined that the management encompasses the fundamental process that is performance management while London et al (2004) explained that the proper implementation of performance management system increases the level of confidence, motivation and commitment and its successful execution depend upon the technique and skills of line manager. Several authors are of same school of thought (see, for example, Newton and Findlay, 1996, Hendry et al., 2000) all further suggested that the organizational success is dependent on the effective implementation of the processes of performance management system by the line manager. Kinnie et al (2005) identified that the accomplishment of a PMS is:"entirely dependent how the line managers have a hold over 
PMS. Purcell et al (2003) added that if PMS is handled optimistically and ardently then staff is more likely to be encouraged by line managers.

\section{Objectives}

- Analyze the performance management system of bank Al-Habib in detail and its effectiveness.

- Analyze the problems faced by the staff and appraiser in this system.

- Analyze the steps taken by the appraiser for the improvement of the performances of the employees.

\section{Methodology}

Qualitative and quantitative methodology was chosen to carry out the research paper. It includes interviewing the human resource managers or Human resource managers to trace their know-how and familiarity about PMS and how they appraise their immediate subordinates. The primary data was collected in this paper through interviewing and by making appraise and appraisers fill questionnaire. Secondary data was also collected through other research papers. It's an exploratory study as it examines problems in performance management system at bank Al-Habib. Sampling technique was convenient sampling.

The type of study that's exploratory research is very significant in the initial phases of a research when the problem is unstructured, not well understood and level of uncertainty is at peak. This research type is informal based on experience and investigation. It's highly flexible. (Philips and Pugh, 1987; Webb, 1992; Ghauri et al; 1995)

It explores the current prevailing problem and opportunity in a certain scenario. According to the need and requirements of the research specific issues and variables are revealed.(Webb, 1992).

\section{Data Analysis and Findings}

- Employees were not involved in setting criteria's of performance evaluation.

- Employee performance was strongly linked to monetary rewards.

- Fair performance management system had a direct link with employee motivation and satisfaction.

- Performance management system was less focused towards training and development and more effective towards performance related outcomes.

- Employees are not well aware of the performance appraisal techniques used by their immediate supervisors to measure and evaluate their performances.

- $76 \%$ employees are not allowed to participate in setting the standards for measuring performance while $20 \%$ said they are allowed to participate, whereas 5\% are sometimes allowed to take part in setting standards and methods for measuring performance. 


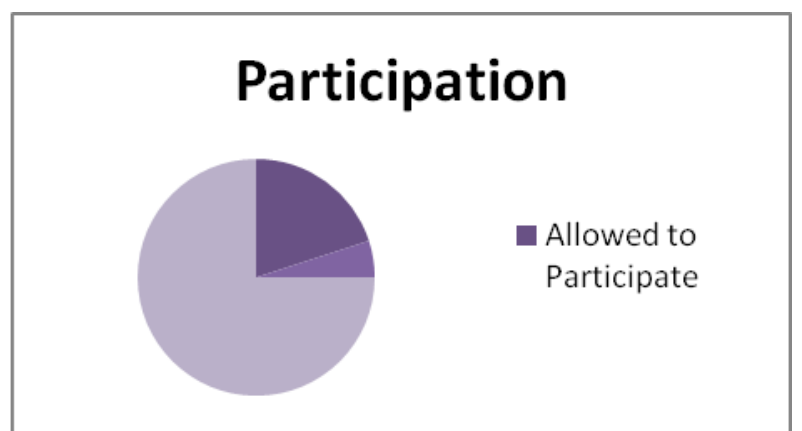

- $73 \%$ people said that appraiser don't meet with each employee for discussing and planning performance appraisal process while according to $27 \%$ said they are involved in the discussions.

\section{Involvement for Appraisal}

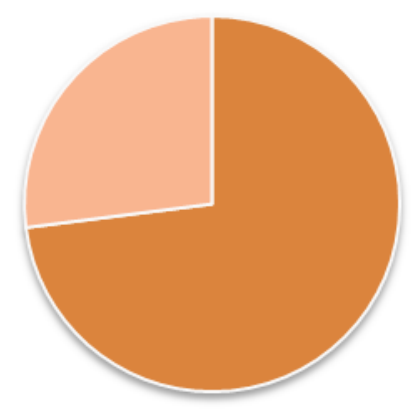

No Discussion with Employees

Involved in

Discussions

- Results showed that $65.85 \%$ respondent said that they agreed with this statement that employee motivation is directly linked with true performance management systems.

- $76 \%$ of the respondents said that true performance management systems increases effectiveness and efficiency of employees.

\section{Performance Management Systems}

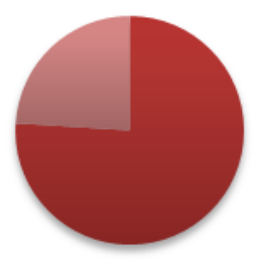

- True performance management systems increases efficiency and effectiveness in employees

- $61 \%$ respondents said that the purpose of the performance appraisal is bonus and 59\% said promotions so it means outstanding performance is rewarded. 


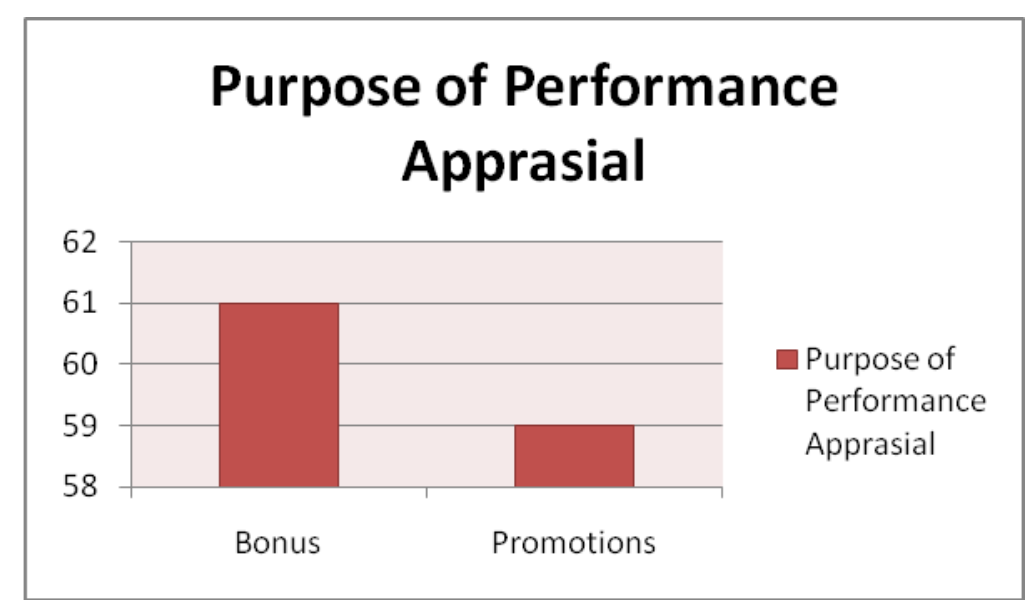

\section{Conclusion and Recommendations}

Performance management system of an organization is really significant as it is directly related to employee's motivation and satisfaction ultimately towards organizational goal achievement.

- There shouldn't be any hidden performance evaluation methods or tool used by an organization that overlaps or reduces the performance of any employee.

- It is very important that employees should know the different methods of performance measurement by which they're being evaluated as the result showed that employees are unaware of performance management tool organization using exactly to appraise them and appraisers should educate their employees about the different methods used for performance appraisal in their organization and let them know about the criteria's.

- Employees must have a clear idea about the assessment system so that they can make proactive measures or get prepared for appraisal accordingly.

- Every employee should have the awareness of the validity and reliability of different performance management methods and systems so that they rest assure about being appraised equally.

- Every employee should be told his appraisal remarks so that he can express his own reasons for poor performance results shouldn't remain confidential it should be open and constructive providing equal opportunities to all.

- Feedback of performance appraisal help employee to have an idea about his knowledge, abilities, strength furthermore the loopholes and demerits. This will definitely improve their performance in next period of time.

- Results showed that majority of the employees said that motivation; job satisfaction and employee loyal are dependent on the performance appraisal.

- If the employees are showing good performance then management will motivate them through some monetary and non monetary rewards, this will ultimate create the loyalty with the organization. 
- There should be a separate board and team called externals to review the performance appraisal so that there is no chance of being prejudice and biased.

- Human resource management should allow the employees to tell whether they are contented with the appraisal or not and where they are confused.

- Results shows that performance appraisal is directly related with job contentment, employee motivation and employee devotion.

- If the management is reinforcing employees high performance appreciating and recognizing it this will ensure longer period stay of an employee in an organization.

- Performance appraisal is conducted annually in Pakistani banks. This process should be conducted twice a year so that we can quickly correct the variations if employee is not profitable for an organization he will remain a continuous cause of loss for an organization over a year. Moreover it indicates key training and development areas and if the workforce of an institute is not contented with the performance management system adopted by the firm then it will ultimately affect the outcome of an organization negatively.

- Performance management systems should focus more towards training and development rather than performance related results.

- Performance system should be de-linked with monetary rewards but with training, development and career advancements opportunities.

- Measurements should be simple to understand by those being evaluated

- Provide measures that allow all employees of the organization to understand how they are influencing the entire business.

\section{Limitations of the Study}

- All domains of performance management and outcome were not investigated.

- Lack of comparison between the employees and managers who participated in the study with the non-respondents.

- Variables applied to different firms might give different results.

\section{References}

Armstrong, M. and Baron, A. (1998a) "Performance Management: the new realities", CIPD, London

Armstrong, M. and Baron, A. (2002) "Strategic HRM: the key to improved businessperformance", CIPD, London

Armstrong, M. and Baron, A. (2005) "Managing Performance: performance management in action”, CIPD, London.

Aguilar, O. (2003). How strategic performance management is helping companies create 
business value. Strategic Finance, 84(7): 44-49.

Beardwell et al (2004) Human Resource Management: A Contemporary Approach, Fourth Edition, FT Prentice Hall, London

Brown, D. (2001) Reward strategies: from intent to impact, CIPD, London

Currie, G. and Procter, S. (2001) "Exploriing the relationship between HR and middle managers” Human Resource Management Journal, Vol. 11, No. 3, pp. 53 - 69

DE WAAL, A. A. and COUNET, H., 2009. Lessons learned from performance management systems Implementations. International Journal of Productivity and Performance Management. 58 (4): 367-390.

DeNisi, A., and Pritchard, R. 2006. Performance appraisal, performance management and improving individual performance: A motivational Framework. Management and Organization Review, 2(2): 253-277.

Dowling, P.J. and Welch, D.E. and Schuler, R.S., (1999), International Human Resource Management, Cincinnati, OH: South-Western.

Fletcher, C. (2001) "Performance Appraisal and Management: the developing research agenda", Journal of Occupational and Organizational Psychology, Vol. 74, pp. 473 - 487

Fletcher, C. (2004) Appraisal and Feedback: Making performance review work, CIPD, London

Ghauri, P., Grnhaug, K. and Kristianslund, I., (1995), Research Methods in Business Studies: A Practical Guide, Prentice Hall, Hemel Hempstead.

Gratton, L. (1996) “The Art of Managing People” Mastering Management 1996

Harrison, R. (2005) Learning and Development Fourth Edition, CIPD, London

Hartog, D. et al (2004) "Performance Management: A Model and Research Agenda" Applied Psychology: An International Review, Vol. 53, No. 4, pp. 556 - 569.

Helm, C., Holladay, C. L. \&Tortorella, F. R. (2007) 'The Performance Management System: Applying and Evaluating a Pay-for-Performance Initiative', Journal of Healthcare Management, vol.52, pp.49-62.

Hendry, C. et al (2000) "Performance and rewards: cleaning out the stables", Human Resource Management Journal, Vol. 10, No. 3, pp. 46 - 62

Kinnie, N. et al (2005) "Satisfaction with HR practices and commitment to the organization: why one size does not fit all" Human Resource Management Journal, Vol. 15, No. 4, pp. 9 29

Locke, E. and Latham, G. (1984) Goal Setting: A motivational technique that works! Prentice Hall International Inc, London

London, M. et al (2004) "Performance Management and Assessment: methods for improved 
rater accuracy and employee goal setting”, Human Resource Management, Vol. 43, No. 4, pp. $319-33626$.

Latham, G. P., Almost, J., Mann, S. \& Moore, C. (2005) 'New Developments in Performance Management', Organizational Dynamics, vol.34, pp.77-87.

Mondy, R. (2008). Human resource management, $10^{\text {th }}$ ed. New Jersey: Pearson Prentice Hall, 224-225.

Moorhead, G. and Griffin, R.W., (1992), Organizational Behavior, Boston: Houghton Mifflin Company.

Newton, T. andFindlay, P. (1996) "PlayingGod The performance of appraisal", Human Resource Management Journal, Vol. 6, No. 3, pp. 42 - 58

Ohemeng, F.L.K., (2009), Constraints in the Implementation of Performance Management Systems in Developing Countries: The Ghanaian Case, International Journal of Cross cultural Management, 9(1), 109-132.

Payant, R. 2006. What's corporate performance management and how does it fit the banking Industry? Journal of Performance Management, 19(3): 3-13.

Philips, E.M. and Pugh, D.S., (1987), How to get a Ph.D., Open University Press, Milton Keynes.

Purcell, J. et al (2003) Understanding the People Performance Link: Unlocking the black box, Research report, CIPD, London.

REPUBLIC OF SOUTH AFRICA (RSA), 1997. White Paper on Human Resource Management for the Public Service. Pretoria: Government Printer.

Rheem, H. 1995). Performance management: A progress report. Harvard Business Review, 73(3): 11-12.

Roberts, G. E. (1998) 'Perspectives on Enduring and Emerging Issues in Performance Appraisal', Public Personnel Management, vol.27, pp.301-320.

Schultz, H. \&Bagraim, J. (2003) Organizational Behavior - A contemporary SouthAfrican perspective. Pretoria, Van Schaiks.

THERON, C.C., 2000. Conformity factor analysis of the performance management audit questionnaire. South African Journal of Psychology. 30 (4): 32-39.

THORPE, R. and BEASLEY, T., 2004. The Characteristics of performance management research: implications and challenges. The International Journal of Productivity and Performance Management. 53 (4): 334-344.

Torrington, D. et al (2005) Human Resource Management, 6th Edition, FT Prentice Hall, Harlow

Webb, J., (1992), Understanding and \& Designing Marketing Research. The Dryden Press, 
London

Weeks, S. (2005) "Performance Management Systems are only as good as management lets them be" Canadian HR Reporter, November 7

Whittaker, S. and Marchington, M. (2003) "Devolving HR responsibility to the line: Threat, opportunity or partnership?” Employee Relations, Vol. 25, No. 3, pp. 245 -261

Williams, R. (2002) Managing employee performance: design and implementation in organizations, Thomson Learning, London.

Excel sheet:

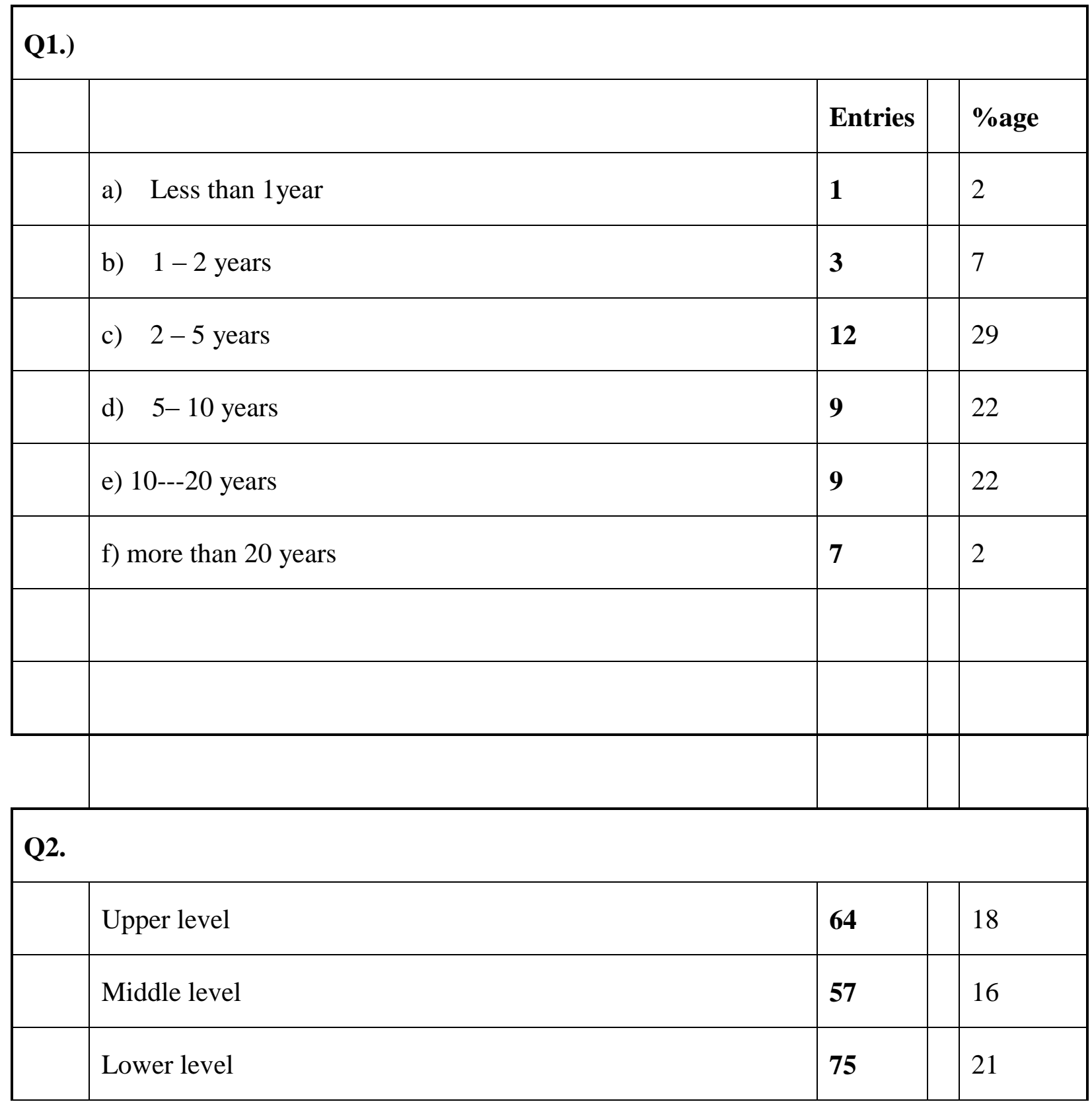




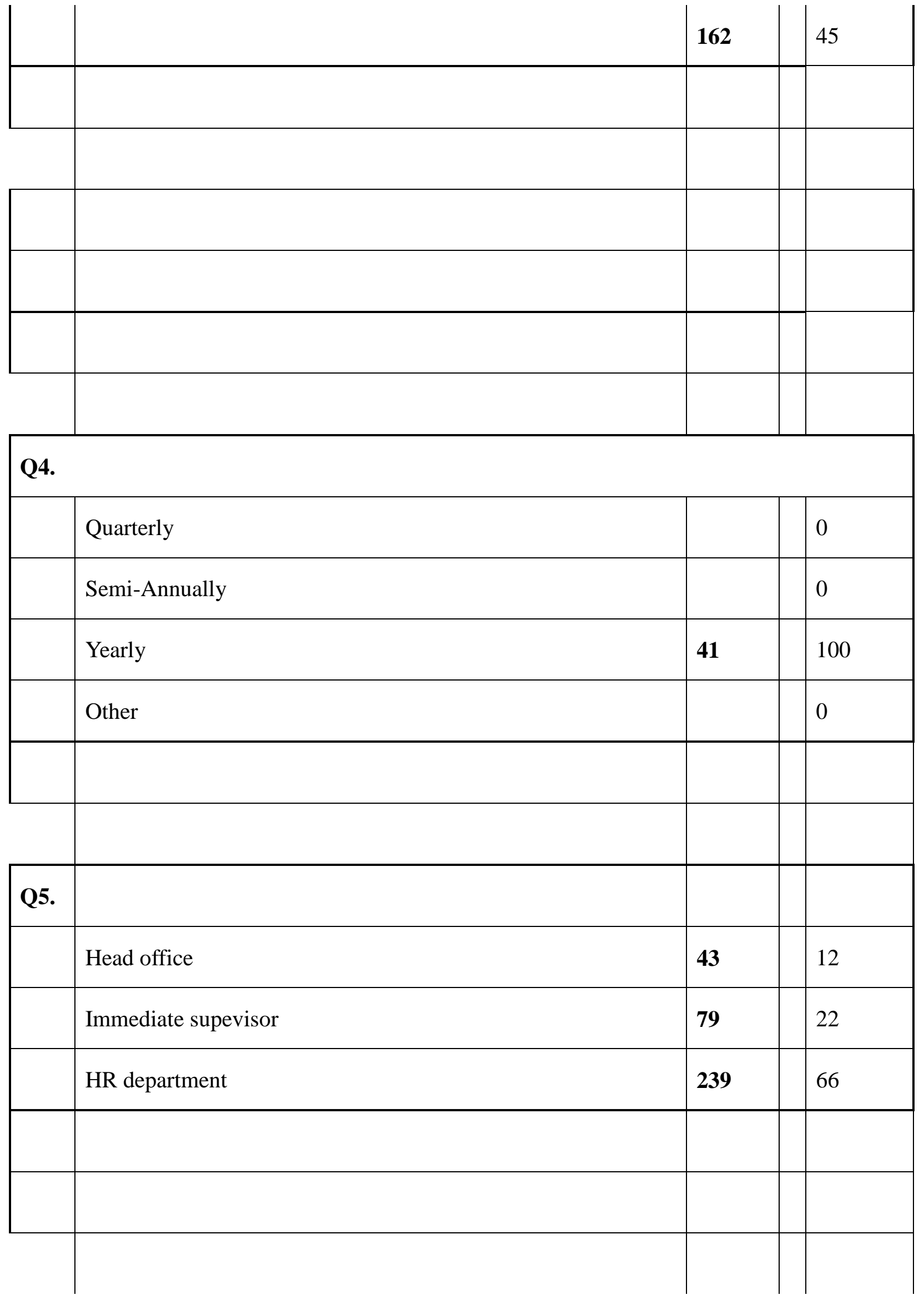


Q6.

\begin{tabular}{|l|l|l|l|l|}
\hline & Yes & $\mathbf{2 7}$ & 66 \\
\hline & No & $\mathbf{1 4}$ & 34 \\
\hline & & & & \\
\hline
\end{tabular}

Q7.

\begin{tabular}{|l|l|l|l|}
\hline Designation wise & $\mathbf{2 7}$ & 66 \\
\hline $\begin{array}{l}\text { Management wise Like Dean , Chairman/ } \\
\text { faculty }\end{array}$ & Other & $\mathbf{0}$ & 0 \\
\hline & & & 0 \\
\hline
\end{tabular}

Q8.

\begin{tabular}{|c|c|c|c|}
\hline & Salary Decisions & 16 & 39 \\
\hline & Bonus & 25 & 61 \\
\hline & Counseling & 6 & 15 \\
\hline & Layoffs & 7 & 17 \\
\hline & Training needs & 3 & 7 \\
\hline & Promotions & 24 & 59 \\
\hline & Transfers & 6 & 15 \\
\hline \multicolumn{4}{|c|}{ Q9. } \\
\hline & Graphic Rating Scales & 3 & 7 \\
\hline
\end{tabular}




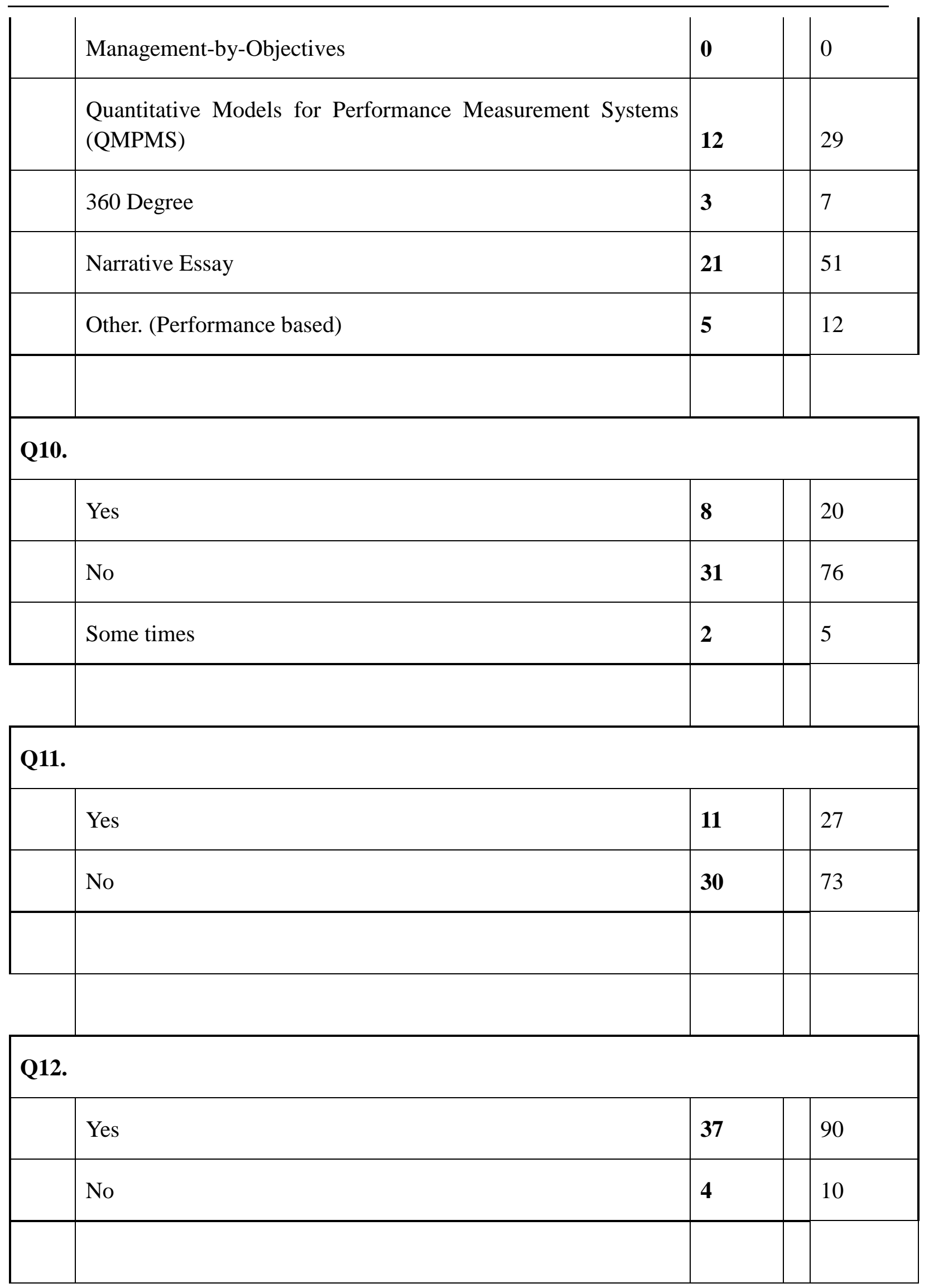




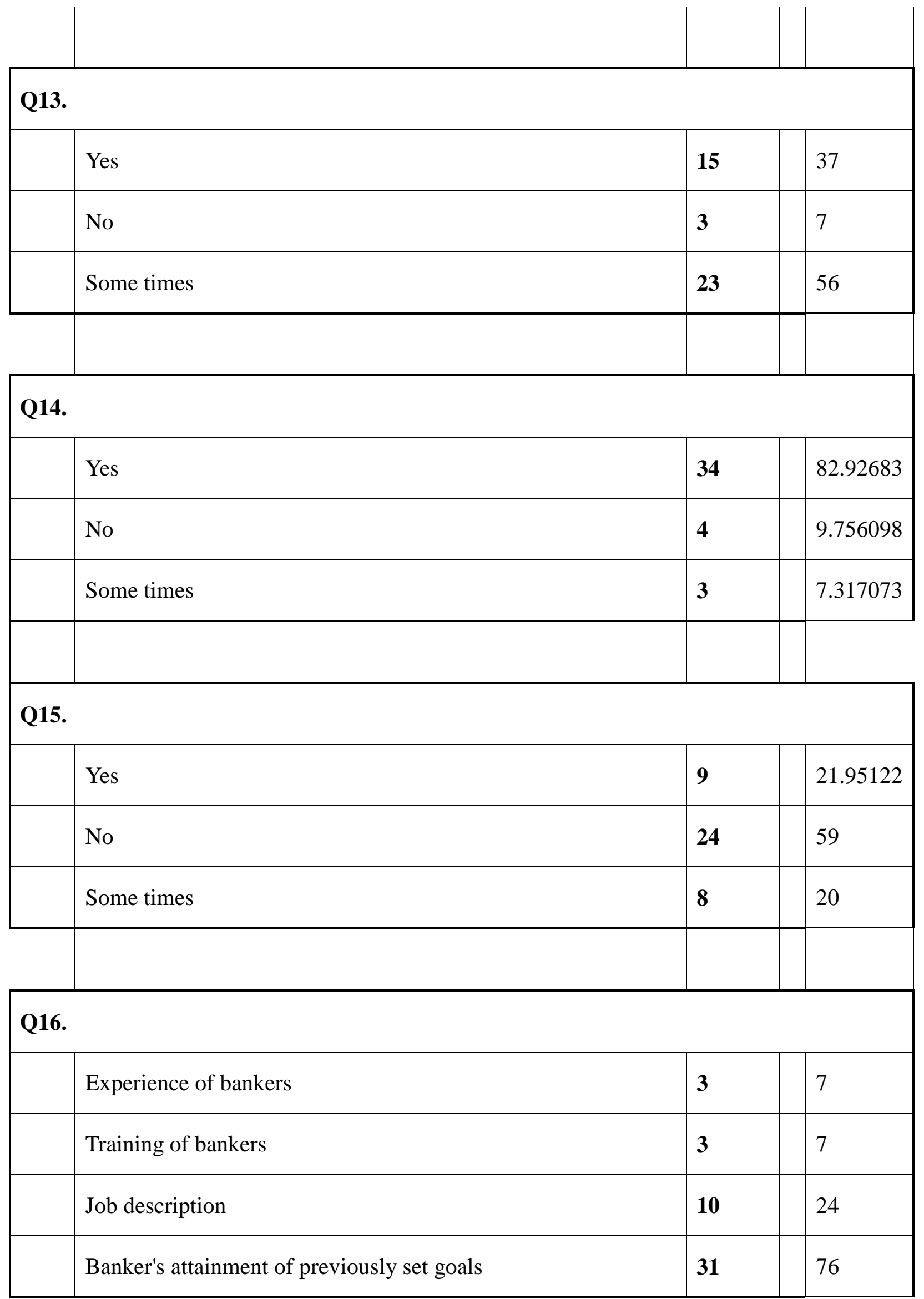




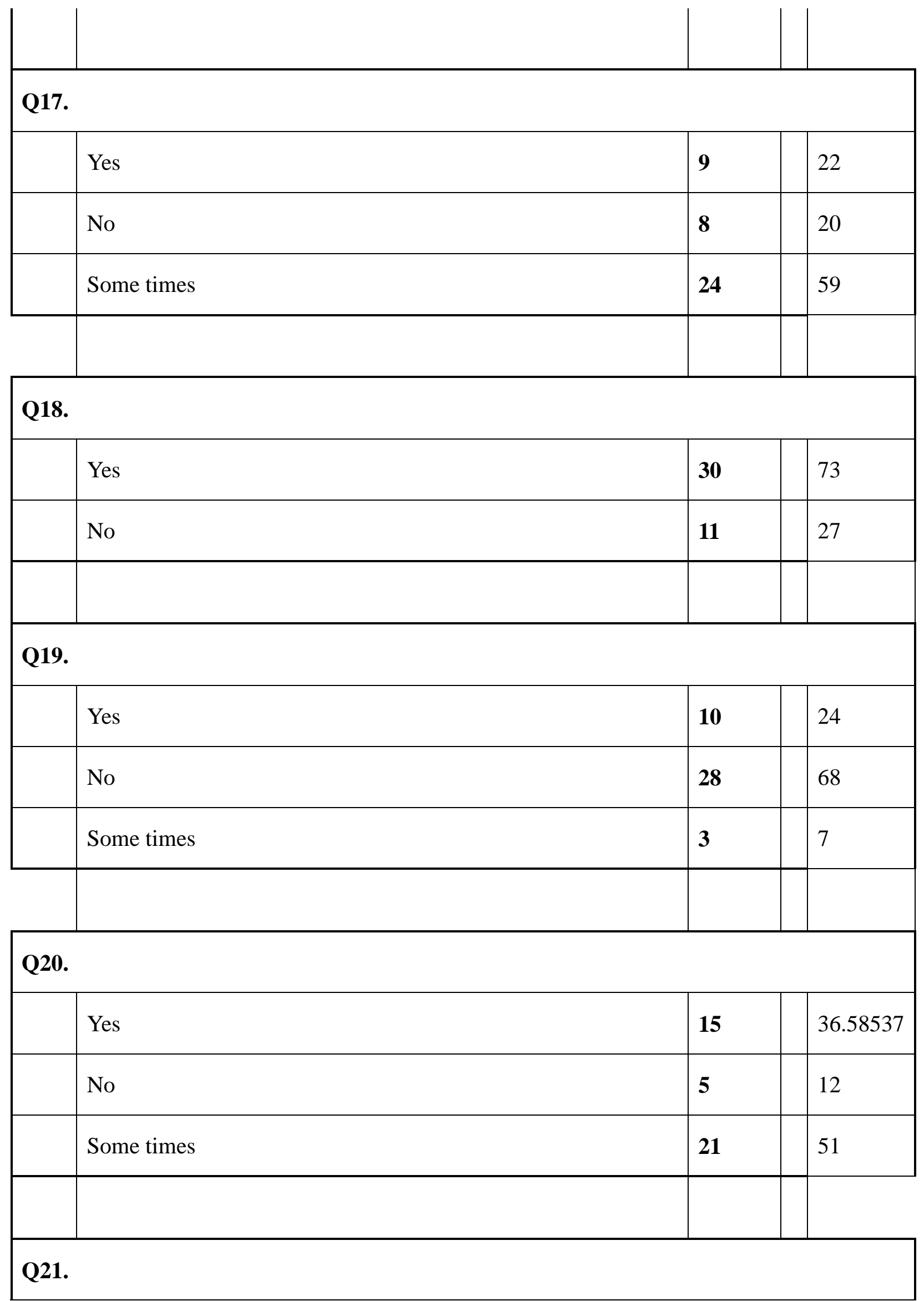




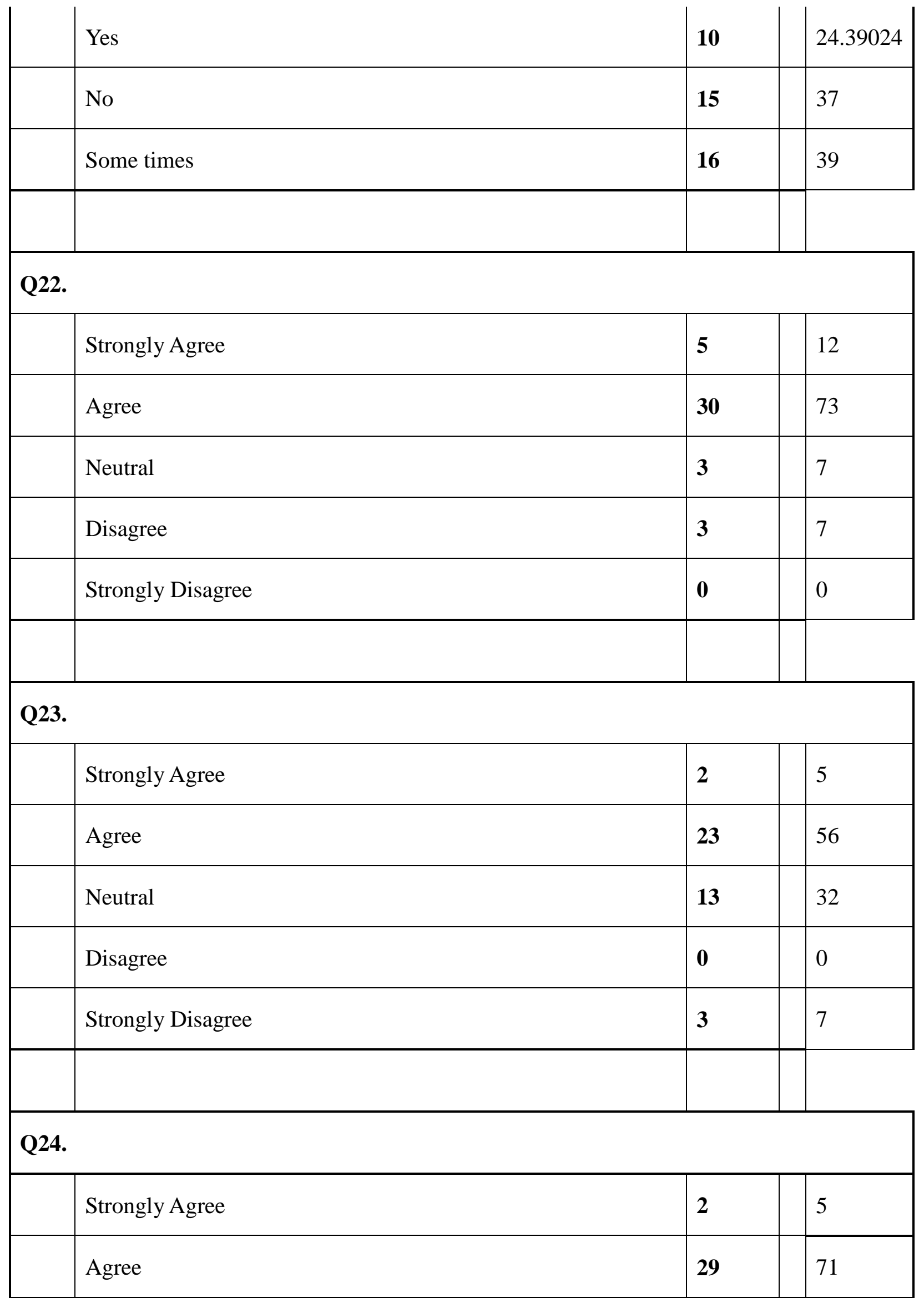




\begin{tabular}{|c|c|c|c|}
\hline & Neutral & 5 & 12 \\
\hline & Disagree & 5 & 12 \\
\hline & Strongly Disagree & $\mathbf{0}$ & 0 \\
\hline \multicolumn{4}{|c|}{ Q25. } \\
\hline & Strongly Agree & 5 & 12 \\
\hline & Agree & 31 & 76 \\
\hline & Neutral & 3 & 7 \\
\hline & Disagree & 2 & 5 \\
\hline & Strongly Disagree & $\mathbf{0}$ & 0 \\
\hline \multicolumn{4}{|c|}{ Q26. } \\
\hline & Strongly Agree & 8 & 19.5122 \\
\hline & Agree & 27 & 65.85366 \\
\hline & Neutral & 4 & 10 \\
\hline & Disagree & 2 & 5 \\
\hline & Strongly Disagree & $\mathbf{0}$ & 0 \\
\hline \multicolumn{4}{|c|}{ Q27. } \\
\hline & Strongly Agree & 5 & 12 \\
\hline & Agree & 31 & 76 \\
\hline
\end{tabular}




\begin{tabular}{|l|l|l|l|l|l|}
\hline & Neutral & $\mathbf{1}$ & 2 \\
\hline & Disagree & Strongly Disagree & $\mathbf{4}$ & 10 \\
\hline & & $\mathbf{0}$ & 0 \\
\hline Q28. & & & & \\
\hline & Strongly Agree & $\mathbf{1 1}$ & 27 \\
\hline & Agree & $\mathbf{2 4}$ & 59 \\
\hline & Neutral & $\mathbf{4}$ & 10 \\
\hline & Disagree & $\mathbf{2}$ & 5 \\
\hline & Strongly Disagree & $\mathbf{0}$ & 0 \\
\hline
\end{tabular}

Figure 4.3. working experience in banks

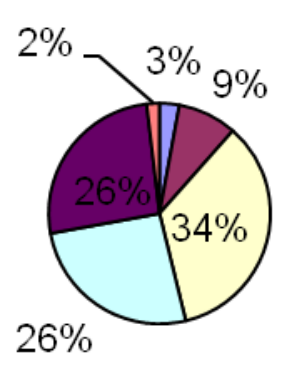

$$
\begin{aligned}
& \text { 口a) Less than 1year } \\
& \text { ab) } 1-2 \text { years } 3 \\
& \text { ㅁ) } 2-5 \text { years } 12 \\
& \text { ㅁ) 5-10 years } 9 \\
& \text { घe) 10---20 years } 9 \\
& \square \text { f) more than } 20 \text { years } \\
& 7
\end{aligned}
$$

Figure 4.1. Designation level

aLiddle level


Figure 4.4. How often is Performance Appraisal for the bankers conducted?

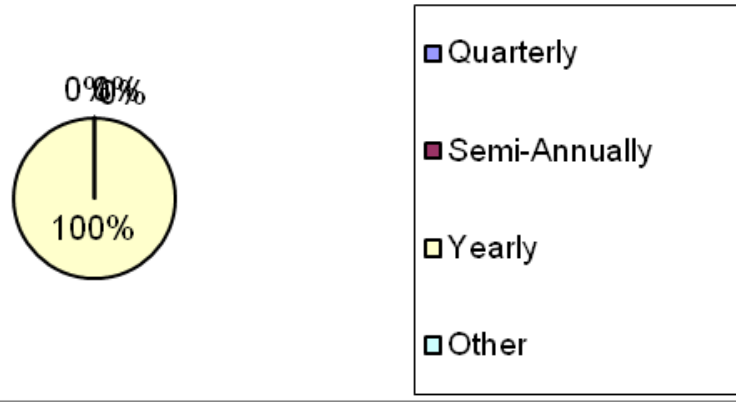

4.8. Is a different performance appraisal form used for different employees?

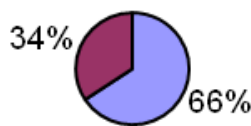

$$
\begin{aligned}
& \text { aYes } \\
& \text { aNo }
\end{aligned}
$$

If a different performance appraisal form is
used, how are the employees divided? $0 \%$

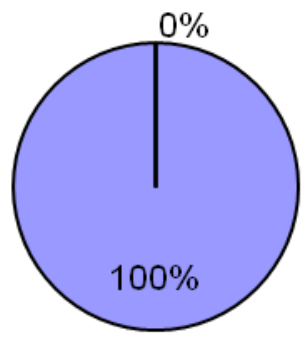

\begin{tabular}{l}
\hline Designation wise \\
Managementwise Like \\
Dean, Chairman/ \\
faculty \\
Other
\end{tabular}



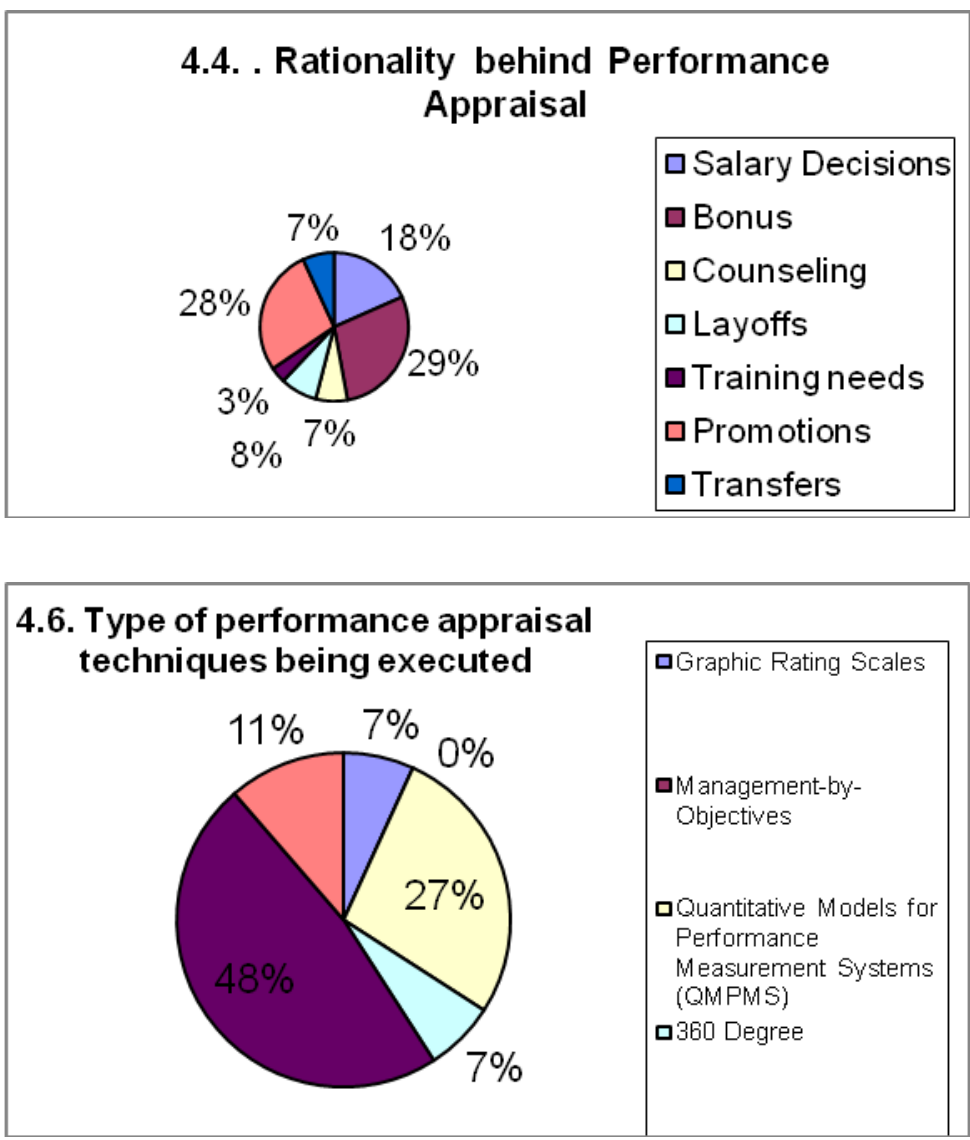

\subsection{Participation of employees in Goals Settings}

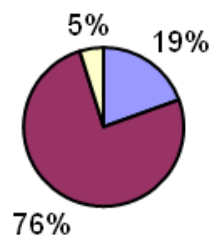

$$
\begin{aligned}
& \text { Yes } \\
& \square \text { No } \\
& \text { aSome times }
\end{aligned}
$$


Are the banker's career objectives and strategy to maximize their career potential considered during performance appraisal?

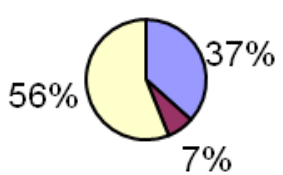

aYes
$\square$ No
$\square$ Some times

Is the performance appraisal planning based on how the employee will do the job, i.e., the behaviors and competencies expected of them?

$10 \%$

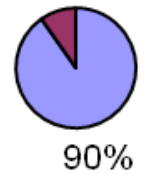

Is the banker's performance viewed in the context of broader organizational goals?

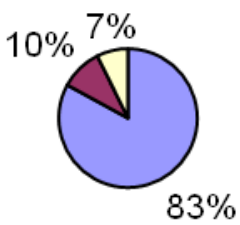

$\square$ Yes
$\square$ No
$\square$ Some times


4.11. Is the opinion of colleagues and customers considered for performance appraisal?

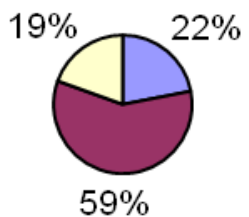

$\square$ Yes
$\square$ No
$\square$ Some times

4.12. During the evaluation, which of the following factors are considered by the

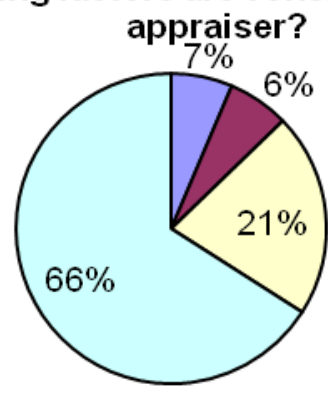
$\square$ Experience of bankers
$\square$ Training of bankers
$\square$ Job description
$\square$ Banker's attainment of
previously set goals

4.13. Is there a performance appraisal review and feedback session occurring in the bank?

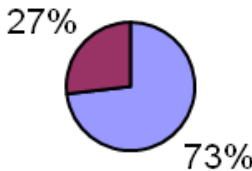

$$
\begin{aligned}
& \text { aYes } \\
& \text { ano }
\end{aligned}
$$

4.14. Does the appraiser discuss the assessment with the employee after the appraisal is over?

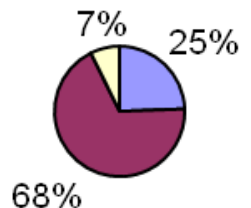

$$
\begin{aligned}
& \hline \text { Yes } \\
& \square \text { No } \\
& \text { aSome times }
\end{aligned}
$$




\section{Macrothink}

International Journal of Human Resource Studies

ISSN 2162-3058

\section{Copyright Disclaimer}

Copyright for this article is retained by the author(s), with first publication rights granted to the journal.

This is an open-access article distributed under the terms and conditions of the Creative Commons Attribution license (http://creativecommons.org/licenses/by/3.0/). 